\title{
NIEUWE UITGAVEN.
}

Mr. Dr. G. M. Verrijn Stuart: De Waarde van het Geld. Rede uitgesproken bij de aanvaarding van het Ambt van Buitengewoon Hoogleeraar aan de Nederlandsche Handelshoogeschool te Rotterdam op den 20en Januari 1922.

Mr. Dr. H. Frijda: De Vorming van den Wisselprijs. Rede uitgesproken bij de aanvaarding van het Ambt van Hoogleeraal aan de Universiteit van Amsterdam den 23 Januari 1922.

Geldtheorie en wisselkoersen zijn onderwerpen, welke elkaar zou nauw raken, dat beide oraties zonder bezwaar in ééne bespreking kunnen worden samengevat, dat eene gedeeltelijk gemeenschappelijke bespreking zelfs eenig voordeel heeft.

Het is wel kenmerkend voor onzen tegenwoordigen tijd, dat de twee nieuwbenoemde Hoogleeraren tot punt van onderzoek hebben genomen onderwerpen, zoo nauw verwant, bijna identiek. Is niet de wisselkoers of wisselprijs, om met Prof. Frijda te spreken, de waarde van het geld van het eene land, uitgedrukt in dat van het andere land?

Er zijn thans ook zeker weinige economische vraagstukken, die zoo zeer ieders aandacht hebben en verdienen als juist deze. Niet ten onrechte noemt Prof. Frijda het valutavraagstuk het gesprek van den dag in gezin, aan toonbank en in scheersalon. De societeit wordt niet genoemd, zeker omdat zij over haren bloeitijd reeds lang heen is.

Geen wonder, dat het vraagstuk zich in ieders belangstelling mag verheugen, als men bedenkt, hoe geweldig het in het geheele economische leven ingrijpt, hoe groote wijziging de veranderingen in de waarde van het geld in de verdeeling van het volksinkomen heeft teweeg gebracht, hoe de geheele handel door de valutaontreddering vrijwel op losse schroeven is komen te staan en meermalen tot niet veel meer dan kansspel is verlaagd.

Beide schrijvers gispen de ongewenscht scherpe tegenstellingen in opvatting, maar vooral in woorden, tusschen de beoefenaren 
der economische wetenschap. De een wijst op de werkelijk dwaze scheiding in twee kampen, een van als theoretici gebrandmerkten en een van zich gaarne practici noemenden, de ander op die elkaar soms fel bestrijdende aanhangers van verschillende meeningen over den grondslag van den loop der wisselkoersen: de aanhangers van de leer van de handelsbalans en die van de leer der koopkracht-pariteit.

Prof. Verrijn Stuart spreekt de hoop uit, dat overbrugging der noodeloos opgeschroefde tegenstellingen op economisch gebied in de naaste toekomst mogelijk zal blijken. Prof. Frijda doet ecn poging de verschillende opvattingen ten aanzien van den wisselkoers met elkaar te verzoenen.

Een dergelijk streven tot verzachting der tegenstellingen is te prijzen, indien althans naar vrede wordt getracht door het bijbrengen van betere inzichten, welke beide partijen bevredigen, niet wanneer die vrede moet worden verkregen door het op een akkoordje te gooien. De wetenschap beoogt uitsluitend het vinden der waarheid; voor transacties is bij haar geen plaats.

Te meer voor een, bij beide Hoogleeraren gelukkig tot uiting komend, streven om andersgezinden te begrijpen. Meermalen blijkt bij zoodanig streven, dat het verschil in opvatting bij tegenstanders niet zoo groot is als werd vermoed. Om tot wederzijdsch begrijpen te komen is duidelijkheid en ondubbelzinnigheid in terminologie vóór alles geboden. Technische termen kunnen hun nut hebben bij gedachtenwisseling tusschen deskundigen, maar ook dan alléén, wanneer omtrent de beteekenis dier termen volkomen eenstemnigheid heerscht. Het ongeluk wil, dat dit in de economie haast nimmer het geval is. Ter illustratie diene, dat Prof. Verrijn Stuart wegens de onvastheid van het begrip nominalist zelf niet weet of hij zich zoo moet noemen. Indien echter de beteekenis van zulke algemeen gebruikte woorden onzeker is, sticht het gebruik ervan veel kwaad. Men late ze dus liever achterwege of lichte, zooals Prof. Verrijn Stuart, de beteekenis ervan duidelijk toe. Dit laatste geschiedt echter te zelden. Maar indien ieder een andere beteekenis aan gelijkluidende woorden hecht, kan men niet verwachten, dat men het eens wordt en indien men het eens meent te zijn, vergist men zich. Men begrijpt elkaar niet. Daarom zij men op zijn hoede voor alle kunsttermen. Tot deze reken ik ook uitdrukkingen als ,reëele rente" in tegenstelling met ,geldrente". Gelukkig, dat Prof. Verrijn Stuart, haar gebruikende, tegelijk een 
omschrijving geeft van hetgeen hij ermede bedoelt. Het woord reëele rente geeft niet een voor ieder vaststaand begrip aan, evenmin als b.v. het woord kapitaal.

Behalve een streven naar het wegnemen van de scherpe kanten bij de tegenstellingen in de economische opvattingen, bestaat belangrijker overeenkomst tusschen beide schrijvers. Prof. Frijda doet uitdrukkelijk de moderne prijstheorie gelden ook voor de wissels. Prof. Verrijn Stuart doet hetzelfde voor de waarde van het geld.

Staan dus beide Hoogleeraren op eenzelfden bodem, het feit, dat de een zijn aandacht in het bijzonder aan de wisselkoersen wijdt, de ander aan de waarde van het geld in het algemeen, maakt, dat beider betoog niet dezelfde banen volgt. Daarom geef $i k$ er de voorkeur aan verder ieders rede afzonderlijk te beschoulwen. Het ligt in mijn voornemen slechts hier en daar een greep te doen uit de behandelde stof.

In de eerste plaats dus eenige opmerkingen over de rede van Prof. Frijda.

Terecht wijst deze er op, dat de concurrentie van landen met dalende valuta bevat een geschenk van die landen aan het buitenland, waarover men zich in landen als Duitschland dus niet behoeft te verheugen, terwijl dat geschenk ook voor de landen, aan welke het ten deel valt, geen onverdeeld voordeel beteekent. Bescherming tegen die geschenken acht schr. niet absoluut verwerpelijk. Alle wapenen uit het rijk voorziene arsenaal van de leer van den vrijhandel tegen deze uitlating te voorschijn te halen, lijkt mij hier niet noodig. Ik moge er hier mede volstaan met te wijzen op het hellende vlak, waarop men zich met deze evenals met alle andere bescherming begeeft.

Zooals wij zeiden, behandelt schr. de vraag of de wisselkoersen afhankelijk zijn van de betalingshalans of van de verhouding in koopkracht van het geld in de verschillende landen. Schr. neigt blijkbaar tot de laatste leer. Hij schaart zich althans onder de bestrijders van cie leer van de betalingsbalans, al wil hij aan deze eene concessie doen. Hij wijst erop, dat de vraag naar wissels tweëerlei grond kan hebben. $\mathrm{Zij}$ kan strekken tot delging van bestaande schulden aan het buitenland, maar ook tot het ondernemen van nieuwe transacties. De vraag naar wissels voor laatstgempent cioel hoidt nauw verband met de prijzen in binnen- en buitenland, de vraag naar wissels tot betaling van aangegane 
verplichtingen is echter onafhankelijk van prijsverschillen, hare bevrediging moet vrijwel tot elken prijs geschieden. De vraag naar wissels uit dezen hoofde kan alzoo tijdelijk den wisselkoers belangrijk van de koopkracht-pariteit dọen afwijken.

Dit betoog is duidelijk en m.i. te aanvaarden. Het is ook geheel in overeenstemining met de door den ondergeteekende gehuldigde opvatting, dat de betalingsbalans weliswaar in eerste instantie de wisselkoersen beheerscht, maar dat die balans op haar beurt weder afhankelijk is van de onderlinge waardeverhouding der munteenheden van de landen, waartusschen het wisselverkeer plaats heeft. Nieuwe, de betalingsbalans mede bepalende, transacties immers worden onmiskenbaar door de koopkracht van het geld in de verschillende landen ten sterkste beinvloed. Door het uitlokken van nieuwe transacties heeft afwijking van de koopkracht-pariteit de strekking zich zelf te vernietigen. Het is te betreuren, dat Prof. Frijda dit tijdelijk karakter van alle afwijkingen van de koopkracht-pariteit niet meer naar voren heeft gebracht. Niet onwaarschijnlijk had hij dan niet een zoo afwerende houding tegen zijn verzoeningspoging ontmoet, als door Prof. Mr. A. van Gijn werd aangenomen in eene bespreking der oratie in De Nieuwe Financier en Kapitalist van 12 Februari j.l. Zoo heel ver staan in deze Prof. Frijda en Prof. van Gijn m.i. niet van elkaar af. De mogelijkheid van een tijdelijke afwijking van de koopkraclitpariteit wordt ook door den laatste erkend. De scherpte van de Duitsche concurrentie vloeit uit dergelijke afwijking voort. Ook dat die afwijking veelal het gevolg is van reeds aanvaarde verplichtingen (b.v. die tot het betalen eener schadevergoeding of oorlogsschatting) zal Prof. van Gijn niet tegenspreken. Ik meen dus, dat hier wederzijds zonder beginselverzaking toenadering tusschen de verschillende kampen mogelijk is.

Dat valutaspeculaties slechts tijdelijke afwijkingen in de wisselkoersen kunnen teweegbrengen, wordt door Prof. Frijda terecht betoogd. Ernstiger verstoring van de koersen, zooals zij de neiging hebben zich te richten naar de koopkracht-pariteit, ducht schr. echter van de arbitrage. Hij oordeelt den invloed daarvan zoo groot, dat hij om dezen een reeds nu terugkeeren tot den gouden standaard voor ons land ontraadt. Deze vrees voor de arbitrage wordt in ruimen kring gevonden. Dat zij echter ook schr. nog houdt bevangen, wekt teleurstelling, nu reeds zoo dikwijls is aangetoond en nimmer is weerlegd; dat wegstroomen van 
al ons goud of zelfs van het grootste deel daarvan van terugkeer tot den gouden standaard nict is te duchten. Dat Prof. van Gijn zich hier vierkant tegenover den Heer Frijda stelt is volkomen begrijpelijk. Waar Prof. Frijda de gewone beweringen der zakenmenschen tot de zijne maakt zonder aan de gebruikelijke argumenten van bijzondere omstandigheden enz. iets toe fe voegen, verlaat hij m.i. den juisten wetenschappelijken grondslag zijner oratie. Na hetgeen reeds over dit onderwerp telkens en telkens is gezegd heeft het geen nut hem in die beweringen te volgen.

Thans de rede van Prof. Verrijn Stuart. Zooals ik reeds opmerkte, berust het daarin vervatte betoog op gezonden grondslag door erkenning van de gelding van de moderne waardeleer ook voor het geld. Op dezen grondslag wordt consequent voortgebouwd, zoodat voor critiek weinig plaats is. Een excerpt te leveren uit schr. beschouwingen heeft weinig zin. Aan wie belang stelt in het behandelde onderwerp zij lezing der oratie zelve aanbevolen. Ik zal dus met eenige korte opmerkingen volstaan. Moge niemand daarin een gebrek aan waardeering zien. Hetgeen eigen opvattingen zeer nabij komt, geeft uiteraard niet tot uitvoerige beschouwingen aanleiding.

Op blz. 11 stelt scir. de vraag, hoe het komt, dat papiergeld, teekengeld en ook bankpapier (b/z. 14) als ruilmiddel dienst doen. Hij zoekt de verklaring ervan in de mogelijkheid die betaalmiddelen te bezigen tot delging van schuld aan den emittent; staat of bank. Maar waarom juist aan den emittent? De wetenschap of het vertrouwen, dat die ruilmiddelen algemeen als zoodanig worden aangenomen, verklaart, dunkt mij, beter en afdoende, dat ze door ieder individueel worden aanvaard, begeerd en dus bruikbaar zijn.

Op blz. 27 noemt schr., in overeenstemming met de leer van de Oostenrijksche school, credietverleening niet anders dan ruil van aanwezig geld tegen geld in de toekomst. Waar hij echter daarop laat volgen, dat de prijs, die voor het te creëeren bankgeld wordt gevraagd, is de debetrente, welke de bank haren debiteur in rekening brengt, drukt hij zich, m.i. niet volkomen juist uit. De prijs is niet die rente alleen, doch de vordering op clen credietnemer (het toekomstige geld voor den credietgever) plus de rente.

Terugkeer tot den gouden standaard wordt door schr. wenschelijk geacht, niet ondat hij dien ideaal vindt, maar omdat hij 
voor hetgeen hij het meest wenschelijk oordeelt, den tijd nog niet rijp acht, n.l. voor een handhaving van de waardevastheid van het geld door middel van een wisselend bankdisconto, gebaseerd op een periodiek vast te stellen indexcijfer. Helaas, de mentaliteit van de directies der circulatiebanken is er niet naar om te mogen veronderstellen, dat de tijd, waarin met vol vertrouwen naar een dergelijke regeling kan worden gestreefd, spoedig zal aanbreken. Schr.'s raad om voorshands een meer bereikbaar doel, n.l. den gouden standaard, voor oogen te stellen, ondersteun ik dan ook ten volle.

Naar dat doel moet onvermoeid worden gestreefd en wel. voortdurend en zonder talmen. Aangenaam doet daarom aan de uitspraak op blz. 46, dat het terugbrengen o.a. van den Nederlandschen gulden op goudwaarde ook zonder internationaal overleg kan geschieden, al kan zulk overleg ook nuttig zijn met het oog op tijdstip en wijze van doorvoering van verschillende maatregelen.

Tenslotte nog een kleine opmerking ten aanzien van schr.'s beoordeeling van het plan-Vanderlip, welke be- en veroordeeling ik in het algemeen onderschrijf. Schr. vreest echter, dat afgezien van andere bezwaren, de wet van Gresham het plan wellicht spoedig onuitvoerbaar zoll maken. Deze vrees lijkt mij ongegrond, indien maar niet een vaste waardeverhouding tusschen oude en nieuwe munt wordt vastgesteld.

Amsterdam, 12 Maart 1922.

W. C. MEES R. AzN. 